\title{
Calvarial Osteoclasts Express a Higher Level of Tartrate-Resistant Acid Phosphatase Than Long Bone Osteoclasts and Activation Does not Depend on Cathepsin K or L Activity
}

\author{
S. Perez-Amodio · D. C. Jansen · T. Schoenmaker • \\ I. M. C. Vogels · T. Reinheckel - A. R. Hayman · \\ T. M. Cox $\cdot$ P. Saftig $\cdot$ W. Beertsen $\cdot$ V. Everts
}

Published online: 14 February 2007

(C) Springer Science+Business Media, Inc. 2007

\section{Erratum to: Calcif Tissue Int (2006) 79:245-254}

DOI 10.1007/s00223-005-0289-z

Due to a production error in the text, but not in the figures, TRAP should be read as TRACP.

The online version of the original article can be found under doi:10.1007/s00223-005-0289-z.

\footnotetext{
S. Perez-Amodio - D. C. Jansen · T. Schoenmaker ·

W. Beertsen

Experimental Periodontology, Academic Center for Dentistry Amsterdam, Universiteit van Amsterdam and Vrije Universiteit, Louwesweg 1, 1066 EA Amsterdam, The Netherlands
}

\section{M. C. Vogels}

Department of Cell Biology and Histology, Academic Medical Center, Universiteit van Amsterdam, P.O. Box 22700,

1100 DE Amsterdam, The Netherlands

\section{T. Reinheckel}

Department of Molecular Medicine and Cell Research, Albert-Ludwigs-Universität Freiburg, Freiburg 79104, Germany
T. M. Cox

Department of Medicine, University of Cambridge, Addenbrooke's Hospital, Hills Road, Cambridge CB2 2QQ, UK

\section{P. Saftig}

Biochemical Institute, Christian-Albrechts University, Olshausenstr. 40, 24098 Kiel, Germany

\section{Everts $(\square)$}

Department of Oral Cell Biology, Academic Centre for Dentistry Amsterdam, Universiteit van Amsterdam and Vrije Universiteit, Van der Boechorststraat 7, 1081 BT Amsterdam,

The Netherlands

e-mail: V.Everts@vumc.nl

\author{
A. R. Hayman \\ School of Clinical Veterinary Science, University of Bristol, \\ Langford, Bristol BS40 5DU, UK
}

